\title{
TAXATION Changes AND THE Cross-Border Pricing of REITs
}

\author{
Trevor W. Chamberlain and Hesam Shahriari
}

A web appendix for this paper is available at:

http://dx.doi.org/10.15239/j.brcacadjb.2016.06.01.wa05

The authors would like to thank two anonymous reviewers of the fournal for their helpful comments. Please address correspondence to Trevor Chamberlain, DSB 304, DeGroote School of Business, McMaster University, 1280 Main Street West Hamilton, Ontario L8S 4M4.

Email: chambert@mcmaster.ca. Telephone: (905) 525-9140 x23980. Fax: (905) 521-8995.

\begin{abstract}
On November 21, 2005 the Canadian government announced a reduction in the tax on dividends in an effort to neutralize the tax system's bias in favour of income trusts. Eleven months later, on October 31, 2006, a new government changed direction and eliminated the tax deductibility of income trust distributions altogether. Exempted from this change in policy was the real estate investment trust (REIT) sector.
\end{abstract}


This present study examines the return behaviour of both Canadian and U.S. REITs around the time of these announcements in an effort to inform the ongoing discussion about REIT taxation design in the United States and abroad. Ordinary least squares with dummy variables are used to estimate Canadian REIT returns using a variant of the market model on the event date and the day after. Both equally-weighted and value-weighted portfolios are created in order to check the robustness of the results. In addition, the relationships between Canadian REIT returns and U.S. REIT returns are examined for each event. Test results indicate statistically significant abnormal returns for the Canadian REITs relative to their U.S. counterparts on both dates.

Keywords: Asset Prices, REITs, Taxes

\section{INTRODUCTION}

In February 2014 Congressional Ways and Means Committee Chairman David Camp released the Tax Reform Act of 2014, a long-awaited plan for broad changes in the U.S. federal income tax. One aspect of the Camp bill that has received particular attention is a proposal to limit REITeligible assets and impose new taxes on companies that convert from corporations to REITs (Borden, 2015). ${ }^{1}$

The consequences for firms and investors of the draft legislation or an alternate proposal will not be known with certainty until such time as it is approved and markets react. However, the raison d'être for REITs is the premise that a competitive tax structure is necessary to attract funds into the high-risk real estate industry. Otherwise, investment capital earmarked for real estate would flow to other sectors or to other tax jurisdictions, particularly those with close economic ties. ${ }^{2}$

The cross-border effects of taxation changes are often acknowledged, but seldom studied. Slemrod (1992) suggests that the high level of integration between the U.S. and Canadian economies provides a natural 
setting for studying cross-border tax effects. The effects of Canadian tax changes on the United States are difficult to measure directly because of the vast difference in size between the two economies. However, the impact of Canadian REIT-related tax changes on the value of Canadian REITs relative to their US counterparts can be quantified. This is the goal of the present study, in an effort to contribute to the current discussion about REIT taxation in the United States and abroad.

\section{BACKGROUND}

Since 1971 the taxation of income received from Canadian corporations as dividends has been based on the principle of tax integration. That is, income taxed at the corporate level and then paid out to shareholders in dividends generates a tax credit intended to offset the tax paid by the corporation. When this provision was introduced, the integration was practically complete and double taxation of corporate income paid out in dividends was eliminated. However, over time, as the national debt ballooned, the value of the tax credit was reduced as subsequent governments sought to increase revenues.

In response, Canadian firms began to insert income trusts between the operating corporation and its owners. These entities would own up to one hundred percent of the equity of the corporation. Most of the cash flow generated by operations - interest, dividends and return of capital - would be distributed to trust unitholders. Interest payments would be paid out of pre-tax income, while dividends would be paid out of after-tax income. The income trust would recapitalize the corporation to ensure that its current tax liability was minimal, if not zero. Instead, the operating income earned at the corporate level would flow through the income trust to unitholders and be taxed at the relevant rate at the personal level. The net result is that income generated by operations at the corporate level would only be taxed once, as was originally contemplated by the Income Tax Act revisions in $1971 .^{3}$ 
The proliferation of income trust conversions and new income trusts beginning in the 1990's represented a significant loss of tax revenue. In response, between November 2005 and October 2006, successive governments announced two very different changes in tax policy. The first announcement, on November 23, 2005, to take effect in taxation year 2006, proposed to lower the personal tax rate on dividend income to eliminate the advantage to individuals of receiving business income via an income trust. However, the policy announcement left unchanged the tax advantage of income trusts to foreign investors and nontaxable entities such as pension plans. ${ }^{4}$ The second, by a new government, on October 31,2006 , proposed to eliminate the tax-deductibility of distributions by income trusts, except those of qualifying REITs, ${ }^{5}$ to equalize the tax treatment between income trust distributions and corporate dividends for all investors. This proposal was to take effect in taxation year 2007 for new trusts and corporation-to-trust conversions and in 2011 for existing trusts.

Chamberlain and Shahriari (2012) examined the valuation consequences for Canadian REITs of the tax changes. They found that the November 2005 change, which followed a period of high return volatility and negative cumulative abnormal returns, had a positive and significant impact on the valuation of REITs. The October 2006 change had different implications for REITs than it did for non-REIT trusts. Nonetheless, like the rest of the income trust sector, REITs responded negatively on the day of the announcement and the day following. Cross-sectional tests, moreover, were unable to explain any cross-sectional variation in REIT values as a result of the two announcements, suggesting that they affected all REITs in the same way.

In an effort to inform the current discussion about REIT taxation, the present paper examines whether U.S. REITs behaved in the same way as their Canadian counterparts at the time of these announcements. Real estate companies of each country invest in the other country's real property and investors in each country invest in the other country's real 
estate companies, including REITs. Although the taxation of Canadian REITs did not change as a result of either of these tax announcements (and, thus, did not change relative to the taxation of their U.S. peers), on both dates REIT values changed significantly - positively on the first date and negatively on the second.

The reason given by the Minister of Finance in October 2006 for exempting REITs was that the Canadian government wanted to stay "in sync" with U.S. tax rules, which had exempted REITs from a clampdown on income trusts in the 1980s. The conventional wisdom, as reported in the media at the time, was that Canadian real estate assets would be "gobbled up" by U.S. REITs if Canadian REITs lost their tax exemption. Inasmuch as there is reportedly a significant cross-country component to real estate company returns (Ling and Naranjo, 2012), this raises the question of whether Canadian REITs got caught up in the overall market reaction to the two tax changes or investors were reacting to other conditions in the North American or international real estate market.

In the next section the empirical literature on the valuation effects of tax changes, with particular emphasis on Canadian income trusts, is examined briefly. This is followed by a description of the data and methodology employed in the present study. The fourth section describes and discusses the results of our tests. The paper concludes with a brief summary of the implications of our findings.

\section{LITERATURE REVIEW}

The taxation of corporate distributions is a longstanding topic of discussion among both academics and policymakers. From a public policy perspective, the debate has focused on the desirability of dividends for distributive reasons versus the potential efficiency costs (Poterba et al, 1995). At the level of the firm, the question, as described above, is whether taxes on dividends increase the firm's cost of capital, thereby negatively affecting its ability to create value through new investment. 
The traditional view is that dividends offer non-tax benefits to shareholders that offset their tax cost. The optimal dividend policy for the firm is that at which the marginal tax costs and non-tax benefits are equal (Zodrow, 1991). In addition, taxing dividends in the hands of investors may induce firms to retain earnings rather than pay dividends. Agency theory suggests that this will encourage overinvestment (Jensen, 1986). An alternate view is that the firm's cost of capital is unaffected by the taxation of dividends inasmuch as dividends do not offer any benefits to investors relative to retained earnings. Dividends are only determined residually after all profitable investment opportunities have been undertaken. The tax paid on dividends can thus be viewed as a charge against the firm's equity (Auerbach, 1971).

The traditional view implies that if income trusts are taxed at lower rates than corporations, they will undertake investments that would be rejected by the latter. The literature on income trusts has largely focused on the role of taxes. Hayward (2002) observes that "by interposing a mutual fund trust between the public investors and the operating corporation, the corporation may substantially reduce or eliminate corporate tax at the operating level and pass these savings in the form of higher distributions to investors" (p.1531). Aggarwal and Mintz (2004) show that the double taxation of dividends arising from direct payments by the corporation to shareholders is eliminated by using an income trust. Edgar (2004) argues that income trusts are an example of tax-driven innovation in that they replicate existing securities and, as such, have no non-tax rationale. Halpern and Norli (2006) also describe income trusts as a vehicle whose sole purpose is to shield business income from corporate tax. As for nontax factors, Aguerrevere et al (2005) offer evidence showing that firms using income trusts have tended to be smaller companies with growth opportunities, while Jog and Wang (2005) argue that the high payouts of income trusts relative to those of corporations reduce agency costs.

The valuation impact on income trusts of the November 2005 announcement of a dividend tax reduction was examined by Elayan et al (2009). 
Their results indicate that during the period leading up to the announcement, income trusts experienced significantly negative abnormal returns. This they attribute to an expectation that the government intended to tax income trusts at a level similar to that applied to corporations. The announcement period returns, in contrast, are positive and significant, suggesting investors revised their expectations or that the uncertainty about the government's plans was resolved.

In a closely related study, Amoako-Adu and Smith (2008) considered portfolios of income trusts as well as high dividend stocks, and for both the November 2005 and October 2006 announcements. They found that the 2005 announcement had a positive effect on the values of both groups during the announcement period. Amoako-Adu and Smith interpret their results as indicating that the reduced tax on dividends was favourable for dividend paying firms and that the government's willingness to maintain the non-taxable status of income trusts reassured investors. ${ }^{6}$ As for the 2006 announcement, they found that the values of both groups fell during the announcement period. However, the impact on income trusts was larger. Moreover, the absolute value of the impact on high payout trusts was smaller than on low payout trusts, reflecting, perhaps, the government's decision to defer applying the tax to existing income trusts until 2011.

Finally, as noted above, Chamberlain and Shahriari (2012) found that the November 2005 change had a positive and significant effect on REIT values. The October 2006 change did not affect REITs in the way that it did non-REIT trusts. Nonetheless, like the rest of the trust sector, REITs responded negatively on the announcement date and the day following. However, within a short period REITs regained all of the value they had lost. 


\section{Data Description and Methodology}

In order to examine the relationship between Canadian and U.S. REIT returns at the time of the tax change announcements, two portfolios were created. The Canadian portfolio comprised seventeen REITs listed on the Toronto Stock Exchange (TSX) with available data at the end of the 2004 fiscal year. The portfolio included all of the companies in the COMPUSTAT Canadian database in the "Real Estate Investment Trust" industry category, with additional data obtained from the Canadian Financial Markets Research Centre (CFMRC) summary information database (CFMRC/TSX Annual). ${ }^{7}$ Table 1 lists the REITs included in the Canadian portfolio together with summary financial information.

The U.S. portfolio consisted of fifty-three REITs listed on the New York Stock Exchange (NYSE), the American Stock Exchange (AMEX) or NASDAQ with available data at the end of the 2004 fiscal year. Data were obtained from the Center for Security Prices (CRSP) Files for SIC codes 6798 and 6513. The REITs included in the U.S. portfolio appear in Table 2.

Summary statistics for both equally-weighted and value-weighted versions of the two portfolios appear in Table 3. Portfolios using both weighting schemes are used to check the robustness of the results. The sample comprises 468 return-days for each portfolio with a mean daily return of approximately 0.1 percent, with the Canadian returns being slightly higher and less volatile than the U.S. returns. The period covered by the sample is June 1, 2005 to January 31, 2007. Pearson correlation coefficients for the Canadian and U.S. portfolios are in the 0.31 to 0.34 range.

Event study methodology using a variant of the market model was used to examine the relationship between Canadian and U.S. REIT returns at the time of each of the tax change announcements. In the standard market model, the return of any individual security or portfolio of securities is regressed on the return of a market portfolio. In general, for any security or portfolio $i$ we have (Campbell et al, 1997, Ch 4): 
$\mathrm{R}_{\mathrm{it}}=\alpha_{\mathrm{i}}+\beta_{\mathrm{i}} \mathrm{R}_{\mathrm{mt}}+\varepsilon_{\mathrm{it}}$

$\mathrm{E}\left[\varepsilon_{\mathrm{it}}\right]=0, \operatorname{Var}\left[\varepsilon_{\mathrm{it}}\right]=\sigma^{2}\left(\varepsilon_{\mathrm{i}}\right)$,

where $R_{i t}$ is the time- $t$ return on security $i ; R_{m t}$ is the time- $t$ return on the market portfolio; $\alpha_{i}, \beta_{i}$, and $\sigma^{2}$ are model parameters; and $\varepsilon_{i t}$ is the mean-zero error term, which captures the abnormal return. Model parameters are often estimated over an estimation period before the event and then used to calculate the abnormal returns during the event period.

In the current study, both equally-weighted and value-weighted portfolios of Canadian REITs and U.S. REITs were created. Daily portfolio returns were then used to estimate the following time-series regression model for each event $k$ :

CARET $_{t}=b_{0}+b_{1} U S R E T_{t}+b_{2} D_{k t}+e_{t}$,

where $C A R E T_{t}$ is the daily return on the Canadian REIT portfolio; $U S R E T_{t}$ is the daily return on the U.S. REIT portfolio; and $D_{k t}$ is a dummy variable, which is set equal to 1 on the event day and the day following, and 0 otherwise. Equation (2) is estimated separately for each of the two announcement dates, November 23, 2005 and October 31, 2006, and for both equally- and value-weighted portfolios. Using a dummy variable in the regression allows us to isolate the differential effect, if any, of the announcements on Canadian REIT returns. That is, inasmuch as the long-term relationship between $C A R E T_{t}$ and $U S R E T_{t}$ is measured by $b_{1}$, any abnormal returns on days 0 and 1 are captured by the coefficient of the dummy variable. In addition, assuming that the market for REITs is liquid and efficient, prices would be expected to react to policy changes quickly. The coefficient $b_{2}$ should capture the differential effect of each announcement on the value of the REIT portfolios. None of the Canadian REITs are included in the U.S. REIT portfolio.

The November 23, 2005 announcement only affected the taxation of Canadian REITs slightly, as it did income trusts in general, and left their tax status unchanged for foreign investors. We would thus expect Canadian REIT returns to remain unchanged vis-à-vis U.S. REIT returns. 


\section{The BRC Academy Journal of Business Vol. 6, No. 1}

As for the October 31, 2006 announcement, although it eliminated the tax advantage of non-REIT income trusts, it left the taxation of qualifying REITs unchanged. Thus, once again, one would not expect any decline in Canadian REIT values relative to their U.S. counterparts.

In so far as the first announcement changed the market's expectations about the Canadian government's tax policy intentions, the parameters of the estimation model would be expected to change from the first event to the second. In other words, the same estimation period cannot be used to calculate the abnormal returns for both announcements. Therefore, the valuation impact of each announcement is estimated with a separate regression over a period of 120 trading days before the announcement date to 60 trading days after the announcement date.

\section{Results AND Discussion}

The estimation results for equation (2) appear in Tables 4 through 7 . Tables 4 and 5 show the equally-weighted and value-weighted portfolio results for the 2005 announcement and Tables 6 and 7 present the same information for the 2006 announcement. Figures 1 and 2 show the pattern of incremental returns and cumulative incremental returns, respectively, for the 2005 announcement, whereas Figures 3 and 4 show the corresponding patterns for the 2006 announcement. The patterns are similar for the value-weighted portfolios, which are not presented here.

\section{Results fOR The November 23, 2005 AnNOUnCEMEnt}

As noted earlier, the November 23, 2005 announcement proposed a lower personal tax rate on dividend income to eliminate the advantage to individuals of receiving business income from an income trust, but left the tax advantage of income trusts to foreign investors unchanged. As stated earlier, Chamberlain and Shahriari (2012) found that the abnormal returns on both the announcement date and the next trading day were 
positive and significant at the one percent level. This was in line with the results of Amoako-Adu and Smith (2008) and Elayan et al (2009) for the trust sector in general, which were attributed by the latter to investors' prior expectation that the government intended to tax income trusts at the level at which it taxed corporations.

This inference is consistent with the results reported in Tables 4 and 5 . In both cases the estimated coefficient for $b_{2}$ is positive and significant at the five percent level. That is, while $b_{1}$ (in both tables) indicates a positive and significant (at five percent) relationship between the Canadian and U.S. REIT portfolio returns, the return on the Canadian portfolio is significantly greater on the announcement date. This seems to confirm the hypothesis that the government's decision was not fully anticipated by the market and served as a positive signal to investors in Canadian REITs relative to their US counterparts. The possibility of increased taxes on income trusts had been part of the public discourse up until that time and the government's announcement dispelled those concerns, at least in the short run. It should also have resolved uncertainty in investors' minds as to how the government would proceed. This seems to be confirmed by the mean abnormal return and cumulative abnormal return patterns presented in Figures 1 and 2; the announcement window follows a period of high return volatility. As well, while the Canadian REIT portfolio experienced negative abnormal returns during the period leading up to the announcement, it regained most of its value in a short time.

\section{RESUltS FOR THE OCTOBER 31, 2006 ANNOUNCEMENT}

While the October 2006 announcement removed the tax advantage of most income trusts for all investors, the policy change excluded qualifying REITs (as described in Appendix II). Therefore, the negative effect of the tax change on the valuation of income trusts generally reported in Amoako-Adu and Smith (2008) would not necessarily affect the Canadian REIT portfolio. Nonetheless, Chamberlain and Shahriari (2012) found that the market reaction to the announcement on the 
first trading day following the announcement (November 1, 2006) was negative and statistically significant (at the one percent level). While the abnormal return on the day of the announcement was also negative, it was statistically insignificant, possibly because the announcement was made late in the trading day.

The relationship between the returns on the Canadian and U.S. REIT portfolios in this case is also positive and significant, at $0.01 \%$ for both the equally-weighted and value-weighted portfolios (see Tables 6 and 7). The coefficient for the event dummy is negative, but only significant for the equally-weighted portfolio (at approximately five percent). Though not strong evidence, it does suggest, once again, that Canadian REIT prices were caught up in the market response to the announcement impact on income trusts generally and, as a result, Canadian REITs became less attractive relative to their US counterparts. At the same time, referring to the Canadian REIT portfolio cumulative incremental returns shown in figure 4 (for the equally-weighted case), it is evident that while the market reacted negatively to the announcement when it occurred, the portfolio was able to recover most of its value in a short period after the event. In fact, after fifty days of trading, the REIT portfolio had regained all of the value it had lost during the period leading up to and including the first trading day. That is, as it became clear that the implications for the Canadian REIT sector were slight, the market corrected itself.

\section{Conclusion}

This study examined the implications for the REIT sector of two changes in tax policy introduced by successive Canadian governments in November 2005 and October 2006. The first change, on November 23, 2005, reduced the income tax on dividends, thus considerably narrowing, but not eliminating, the gap in the overall tax paid via the corporate versus income trust form of business organization. The second change, on October 31, 2006, removed the tax advantage of the income trust form, but excluded qualifying REITs. 
While these results do not establish the presence of cross-border spillover effects between Canada and the United States, they do appear to confirm that the change in REIT values at the time of each announcement was attributable to the announcement itself. That is, in both cases, an abnormal return for the Canadian REIT portfolio was observed relative to that of its U.S. counterpart. Inasmuch as the returns on the Canadian and U.S. portfolios followed a similar pattern during the observation period, these abnormal returns are interesting in that as they are arguably not what one would have expected, especially in 2006. However, they are consistent with the premise that tax change announcements do affect security values in one country relative to those in another. An increase (decline) in REIT values implies a lower (higher) cost of capital and an increase (decline) in investment in real estate assets. While tax policy invariably has to balance a number of often competing objectives, our findings suggest that policymakers should proceed with caution as they consider the introduction or reform of taxes that influence investor behaviour.

\section{REFERENCES}

Aggarwal, L., \& Mintz, J. (2004). Income trusts and shareholder taxation: Getting it right. Canadian Tax fournal, 52(3), 792-818.

Aguerrevere, F., Pazzaglia, F., \& Ravi, R. (2005). Income trusts and the great conversion. Canadian Investment Review, 18(4), 8-12.

Amoako-Adu, B., \& Smith, B. F. (2008). Valuation effects of recent corporate dividend and income trust distribution tax changes. Canadian Fournal of Administrative Sciences, 25(1), 55-66. http://dx. doi.org/10.1002/cjas.49

Auerbach, A. J. (1979). Wealth maximization and the cost of capital. The Quarterly fournal of Economics, 93(3), 433-446. http://dx.doi.org/10 $.2307 / 1883167$

Bernstein, J. (April 2007). Income trusts: Non-qualifying REITs. Canadian Tax Highlights, 15, Toronto, ON: Canadian Tax Foundation. 
Borden B.T. (2015). Reforming REIT Taxation or Not. Houston Law Review, 53 (1), 1-102.

Campbell, J. Y., Lo, A. W., \& MacKinlay, A. C. (1997). The Econometrics of Financial Markets, Princeton, NJ: Princeton University Press.

Chamberlain, T. W., \& Shahriari, H. (2012). Asset prices and taxes: an empirical study. BRC Academy fournal of Business, 2(1), 1-25.

Edgar, T. (2004). The trouble with trusts. Canadian Tax fournal, 52(3), 819-852.

Elayan, F. A., Li, J., Donnelly, M. E., \& Young, A. W. (2009). Changes to income trust taxation in Canada: investor reaction and dividend clientele theory. Fournal of Business Finance \& Accounting, 36(5-6), 725-753. http://dx.doi.org/10.1111/j.1468-5957.2009.02156.x

Halpern, P., \& Norli, O. (2006). Canadian business trusts: A new organizational structure. Journal of Applied Corporate Finance, 18(3), 66-75. http://dx.doi.org/10.1111/j.1745-6622.2006.00099.x

Hayward, P. D. (2002). Income trusts: A "tax-efficient" product or the product of tax inefficiency? Canadian Tax fournal, 50(5), 1529-1568.

Jensen, M. C. (1986). Agency costs of free cash flow, corporate finance, and takeovers. The American Economic Review, 76(2), 323-329.

Jog, V., \& Wang, L. (2004). The growth of income trusts in Canada and the economic consequences. Canadian Tax fournal, 52(3), 853-880.

Keenan C. (2015). Coming soon? REITs in India and China. REIT Magazine, Sept/Oct, 14-18.

Ling, D. C., \& Naranjo, A. (2002). Commercial real estate returns performance: a cross-country analysis. Fournal of Real Estate Finance and Economics, 24(1-2), 119-142. http://dx.doi.org/10.1023/A:101393 8506550

Poterba, J. M., \& Summers, L. H. (1985). The economic effects of dividend taxation. In E. Altman, \& M. Subrahmanyam (Eds.), Recent Advances in Corporate Finance (pp. 227-284), Homewood, IL: Irwin Professional Publishing. http://dx.doi.org/10.3386/w1353 
Slemrod, J. (1992). The impact of U.S. tax reform on Canadian stock prices. Ch.7 in J. D. Shaven and J. Whaley (Eds.), Canada-U.S. Tax Comparisons (pp. 237-254), Chicago, IL: University of Chicago Press.

Zodrow, G. R. (1991). On the" traditional" and" new" views of dividend taxation. National Tax fournal, 44(4), 497-509.

\section{Citation Information}

Chamberlain, Trevor W., and Hesam Shahriari. "Taxation Changes and the Cross-Border Pricing of REITs." The BRC Academy fournal of Business 6, no. 1 (2016): 115-129. http://dx.doi.org/10.15239/ j.brcacadjb.2016.06.01.ja05

\section{Web Appendix}

A web appendix for this paper is available at:

http://dx.doi.org/10.15239/j.brcacadjb.2016.06.01.wa05 


\section{Notes}

1. REITs, or real estate investment trusts, are companies that own incomeproducing real estate. Their assets include hotels, nursing homes, shopping malls, office buildings and apartments. Originally created in 1960 in the United States, REITs have spread worldwide and have a significant presence in Canada.

2. Indeed, China and India are contending with this issue presently. In 2014 both countries approved regulations for REITs to be established, but so far neither has settled on a tax structure that would allow them to compete successfully with REITs in Hong Kong, Singapore and Malaysia (Keenan, 2015).

3. The mechanics of the taxation of dividends and distributions using the corporate and income trust in Canada are explained in more detail in Appendix 1.

4. The loss of revenue was acknowledged by the government when the change in tax policy was announced. However, it went on to say that "reducing the tax individuals pay on dividends will encourage savings and investments and will help establish a better balance between the tax treatment of large corporations and that of income trusts" (Canada, Department of Finance, November 23, 2005). Some commentators questioned the claim of equal treatment by pointing to differences between the tax treatments that still favoured income trusts (see Elayan et al, 2009).

5. The criteria for the REIT exemption in Canada are presented in Appendix 2.

6. Another interpretation of this result is that even when the personal and corporate taxes paid on dividend income are set equal to that paid on trust distributions, there are a number of other tax factors that favour the latter (see Elayan et al, 2009).

7. Canadian REITs are listed in the COMPUSTAT annual and quarterly databases under location "CAD" and Standard Industry Classification (SIC) code "6798". Boardwalk Real Estate Trust is an exception, and is classified under SIC code "6513" (the "operators apartment bldgs" industry category). However, it is included in the portfolio since it operates as a Canadian REIT. 